\title{
VISUALITAS FOTOGRAFI: FOTO BUPATI KLATEN DALAM KAMPANYE PILKADA DI TENGAH COVID-19
}

\author{
Prayanto Widyo Harsanto \\ Program Studi Desain Komunikasi Visual, Fakultas Seni Rupa \\ Institut Seni Indonesia Yogyakarta \\ Jalan Parangtritis Km 6,5 Sewon, Bantul, Yogyakarta \\ No. Hp.: +628122696479, E-mail: prayantowh@ymail.com
}

\begin{abstract}
ABSTRAK
Agenda politik tahun 2020 di Indonesia adalah pesta demokrasi untuk Pemilihan Kepala Daerah (Pilkada) secara serentak dengan diikuti 270 wilayah yang bersamaan dengan wabah pandemi Covid 19. Namun, situasi ini memunculkan kampanye terselubung di tengah upaya pemerintah dalam menangani dan mencegah menyebarnya Covid-19. Indikasi munculnya kampanye terselubung di tengah wabah Covid-19 telah dilakukan beberapa kepala daerah, salah satunya oleh Bupati Klaten dengan menyertakan foto diri dalam bantuan sosial (bansos), bahkan juga ditandai dengan munculnya foto kepala daerah di baliho-baliho di berbagai tempat strategis, di media massa, dan di media sosial. Terjadinya fenomena visualitas fotografi yang bersinggungan dengan fenomena politik dalam Pilkada 2020 ini menarik dan penting untuk dikaji. Tujuan kajian ini adalah untuk membaca dan memahami lebih dalam atas intervensi visual secara terus-menerus sebagai bagian esensi komunikasi sosial-politik. Dalam kajian ini digunakan metode kualitatif deskriptif untuk memaparkan secara komprehensif dengan dibantu berbagai literatur. Analisis dilakukan secara kualitatif berdasarkan visualitas sebagaimana metode yang digunakan oleh Gillian Rose (2001). Kesimpulan yang dapat diambil dari penelitian ini adalah bahwa visualitas fotografi yang dimanfaatkan pejabat publik pada media komunikasi visual dapat dilihat sebagai bentuk politisasi sebagai konsekuensi lahirnya upaya penafsiran terhadap fakta atau realitas sosial.
\end{abstract}

Kata kunci: visualitas, fotografi, pilkada, Covid-19, public figure

\section{ABSTRACT}

PHOTOGRAPHIC VISUALITY: Photo of the Klaten Regent in the Regional Election Campaign amidst the Covid-19. The 2020 political agenda in Indonesia was a democratic party for the election of Regional Head (Pilkada) which was simultaneously participated by 270 regions that coincided with the Covid-19 pandemic. However, this situation gave rise to a covert campaign amid the government's efforts to deal with and to prevent the spread of Covid-19. Several regional heads had shown indications of the emergence of covert campaigns in the midst of the Covid-19 outbreak, one of which was the Klaten Regent, who enclosed a photo of himself in the social assistance, and it was even marked by the appearance of the photo of the regional heads on billboards in various strategic places, in the mass media, and in social media in the midst of the Covid-19 pandemic. The phenomenon of photographic visuality that intersected with the political phenomenon of the 2020 Pilkada is interesting and important to study. The purpose of this research is to read and to deeply understand the visual interventions continuously as a part of the essence of socio-political communication. This study used a descriptive qualitative method to describe the whole study comprehensively with the help of various literature. The analysis was carried out qualitatively based on visuality as the method used by Gillian Rose (2001). The conclusion that could be drawn from this research is that the visuality of photography used by public officials in visual communication media can be seen as a form of politicization as a consequence of the birth of attempts to interpret social facts or reality.

Keywords: photographic visuality, Covid-19, pilkada, public figure 


\section{PENDAHULUAN}

Tahun 2020 kembali berlangsung pesta demokrasi untuk pemilihan kepala daerah yang dilaksanakan secara serentak di seluruh wilayah Indonesia, yang diikuti 270 wilayah meliputi 9 provinsi, 224 kabupaten, dan 37 kota. Pemungutan suara pemilihan kepala daerah yang semula dijadwalkan digelar pada 23 September 2020, mundur menjadi 9 Desember 2020. Salah satu kabupaten yang akan melakukan pemilihan kepala daerah adalah Kabupaten Klaten, Jawa Tengah. Kabupaten Klaten memiliki 26 kecamatan, yang dibagi lagi atas 391 desa dan 10 kelurahan. Sejak tahun 1948 sudah ada 19 kepala daerah sebagai bupati silih berganti dan Hj. Sri Mulyani merupakan bupati yang ke19. Pada awalnya Hj. Sri Mulyani merupakan wakil dari Hj. Sri Hartini yang menjadi bupati. Pasangan ini memenangkan Pilkada 2015, tetapi belum genap setahun setelah dilantik pada 17 Februari 2016, Komisi Pemberantasan Korupsi (KPK) menangkap tangan Sri Hartini dengan tuduhan kasus jual beli jabatan itu. Selanjutnya $\mathrm{Hj}$. Sri Mulyani ditunjuk menjadi Plt Bupati Klaten dan selanjutnya dilantik resmi menjadi bupati pada 20 November 2017 menggantikan $\mathrm{Hj}$. Sri Hartini. Masa kepemimpinan Bupati Klaten ini akan berakhir tahun 2021. Untuk itu, Hj. Sri Mulyani yang juga seorang politikus dari PDIP akan maju kembali sebagai calon Bupati Klaten di Pilkada 2020. Pada Pilkada 2020, Hj. Sri Mulyani diprediksi awalnya menggandeng Aris Prabowo untuk menjadi wakilnya. Akan tetapi, dalam perjalanan waktu Aris Prabowo digantikan H. Yoga Hardaya, S.H., M.H. menjadi calon wakil bupati dari partai Golkar.

Merupakan keprihatinan bersama bahwa tahun politik ini berlangsung bersamaan dengan terjadinya wabah pandemi Covid-19 yang melanda dunia, termasuk Indonesia.
Terjadinya pandemi Covid-19 yang bersamaan dengan tahun politik ini dampaknya sangat terasa dan memengaruhi perilaku sosial, politik, ekonomi, dan budaya dalam kehidupan masyarakat. Demikian halnya dengan dunia politik di Indonesia, dengan sendirinya bakal terpengaruh oleh pandemi ini. Wabah pandemi Covid-19 ini berdampak terhadap berbagai lini kehidupan manusia, khususnya secara ekonomi dan sosial. Roda perekonian lumpuh karena masyarakat diimbau untuk bekerja dari rumah (BDR) guna menghindari dan memutus mata rantai penularan virus ini. Berbagai upaya untuk melawan virus ini dilakukan pemerintah pusat dan semua pemimpin daerah, baik menjaga dengan berbagai cara, menghindari virus, maupun dengan membantu kesulitan hidup masyarakat yang terdampak. Upaya pemerintah membantu kesulitan ekonomi antara lain dengan memberikan kebutuhan sembako, dana tunai langsung, berbagai kebijakan keringanan pajak, dan berbagai kegiatan sosial lainnya. Berbagai upaya juga dilakukan agar virus ini tidak menyebar antara lain dengan membagikan hand sanitizer dan sabun cair serta menyemprot lingkungan dan fasilitas publik dengan disinfektan.

Namun, tidak dapat dimungkiri bahwa berbagai upaya dan bantuan pemerintah kepada masyarakat di tengah pandemi Covid-19 tersebut ternyata juga dimanfaatkan oleh beberapa pejabat daerah untuk kampanye terselubung demi meraih jabatan kembali pada periode berikutnya. Badan Pengawas Pemilu (Bawaslu) mengatakan bahwa telah terjadi upaya 'kampanye terselubung' yang berpotensi mengarah pada penyelewengan pidana pemilu yang dilakukan oleh beberapa kepala daerah, yaitu dengan mencantumkan foto kepala daerah dalam bantuan sosial (bansos) kepada masyarakat di tengah pandemi Covid-19. Kepala 
daerah yang mencantumkan foto dalam bantuan sosial itu adalah mereka yang berpotensi besar maju kembali dalam pemilihan kepala daerah berikutnya. Di antaranya adalah kepala daerah di Klaten, Jawa Tengah, beberapa kepala daerah di Provinsi Lampung seperti di Pesawaran, Way Kanan, Lampung Tengah, Lampung Timur, dan Bandar Lampung, kemudian di Pangandaran, Jawa Barat, serta di Sumenep dan Jember, Jawa Timur. Modusnya sama, menempelkan foto dirinya disertai tulisan (pesan) tertentu di sembako bantuan sosial yang diberikan seperti beras, minyak, dan gula. (https://www. tribunnews.com/nasional/2020/04/01).

Salah satu kasus foto diri pejabat daerah yang banyak disorot media dan mendapatkan teguran dari Bawaslu dan gubernurnya adalah Bupati Klaten, Jawa Tengah. Kasus yang ditemukan berkaitan kampanye terselubung di tengah pandemi Covid-19 ini adalah munculnya bantuan hand sanitizer dari kementerian sosial yang dibagikan oleh pemerintah Kabupaten Klaten menggunakan kemasan yang diberi foto wajah Bupati Klaten, disertai pesan verbal atau teks bertuliskan: "Bantuan Bupati Kabupaten Klaten”. Barangkali bagi masyarakat Kabupaten Klaten sudah tidak asing lagi disuguhi foto wajah bupatinya, karena foto wajah Bupati Klaten banyak ditemukan atau banyak terpampang di ruang-ruang publik dan jalan-jalan di wilayah Klaten. Bahkan sudah tidak asing bagi masyarakat di luar wilayah Klaten, terutama mereka yang akan masuk ke wilayah ini karena sudah disambut dengan senyum wajah Bupati Klaten dalam foto yang terpampang melalui media komunikasi visual berbentuk baliho. Semakin masuk ke setiap sudut wilayah, maka semakin banyak ditemukan wajah bupati di baliho, bahkan dalam buku sekolah yang dibagikan untuk anak sekolah pun ada foto wajahnya.
Maraknya pejabat publik atau kepala daerah yang menampilkan foto diri di berbagai media merupakan bentuk komunikasi politik yang senantiasa menampilkan konten dan kode yang merepresentasikan visi misi diri untuk maju sebagai kontestan dalam Pilkada 2020. Fenomena visualitas gambar (fotografi) ini menarik untuk dikaji mengingat aspek tersebut merupakan pendekatan visualitas dalam upaya political branding yang dilakukan sebagai tolok ukur dan sebagai salah satu pertimbangan masyarakat pemilih dalam menentukan pilihan kepala daerahnya kelak. Selanjutnya, yang menjadi pertanyaan dalam kajian ini adalah apakah visualitas fotografi untuk kepentingan politik masih memiliki pengaruh (daya persuasi) yang kuat. Kemudian, bagaimana masyarakat sebagaikonstituenmerespons danmempersepsikan foto kepala daerahnya di berbagai media komunikasi tersebut. Sementara berdasarkan visualitas fotografi dalam kajian ini menggunakan konsep Walter Benjamin, 'photography is politic' untuk menyikapi fenomena sosial, politik, dan ekonomi, ketika digunakan oleh para politikus pada masa pandemi Covid-19. Dalam konteks yang sama Walter Benjamin juga mengatakan bahwa kehadiran fotografi mampu melakukan agitasi dan fotografi merupakan bentuk refleksi intelektual maka membutuhkan landasan, yang tidak lain adalah masyarakat sosial (massa) dan persyaratan yang lain, yaitu politik, ekonomi, dan budaya (Jameson, 1977).

Sebagaimana pemikiran dan yang dikatakan Walter Benjamin, yaitu apakah masih relevan dan efektif kembali diterapkan saat ini? Dengan pola pemikiran kritis seperti yang disampaikan Walter Benjamin "photography is politic", penulis meyakini bahwa dalam perkembangan komunikasi pada era digital dan di tengah masa pandemi Covid-19 ini masyarakat mampu menganalisis dan 
memaknai berbagai fenomena sosial di sekitarnya. Oleh karena itu, visualitas fotografi studi foto kepala daerah di media komunikasi visual pada masa pandemi Covid-19 menarik dan penting untuk diteliti.

Terkait dengan permasalahan fotografi, Benjamin menyebutkan "photography is politic" (Buck-Morss, 1989:132; Jameson, 1977:86). Fotografi merupakan bagian dari budaya populer dan kehadirannya senantiasa berhubungan dengan perasaan politik, dalam hal ini fotografi sebagai interaksi intelektual dapat membentuk sebuah agitasi dalam wujud visual. Benjamin senantiasa mengaitkan hubungan fotografi dengan politik, sebagaimana yang dikatakan bahwa fotografi mampu melakukan agitasi dan fotografi merupakan bentuk refleksi intelektual "in a political sense is agitational". Bentuk baru dalam melakukan agitasi adalah dengan melakukan injeksi yang masif dalam dunia mimpi masyarakat yang paling privat. Maka, tidak berlebihan bila dilakukan rekayasa antara simbol-simbol yang digunakan dalam kampanye politik untuk menginjeksi gagasan sebagai pintu masuk dalam dunia mimpi dalam diri seseorang.

Sementara untuk memahami visualitas fotografi dari kacamata sosiologi, Douglas Harper (2012) dalam bukunya Visual Sociology mengatakan bahwa visualitas gambar/foto merupakan representasi dari produksi nilai sosial yang terefleksi di masyarakat. Pergeseran maupun perubahan nilai-nilai sosial tecermin pula dalam tampilan visual tersebut. Visualitas gambar/ fotografi memiliki kekuatan representasi visual yang lebih kuat dan berbeda dengan kata-kata serta angka. Sebagaimana dikatakan Bruce Barnbaum, bahwa foto sebagai gambaran harfiah dari realitas sosial yang membuatnya menjadi genre seni yang paling kuat di dunia saat ini dan hadir sebagai realitas, kekuatan yang tidak dimiliki oleh genre yang lainnya (Jazuli, 2014; Amala, 2016:136).
Visualitas gambar/foto dari kacamata sosiologi terletak pada tindakan melihat, tidak hanya pada apa yang dilihat tetapi juga pada siapa yang melihat. Terkait dengan kajian ini, dengan munculnya foto diri pejabat publik pada media komunikasi, menunjukkan adanya 'hubungan sosial-politik' yang dimediasi oleh gambar. Foto diri dari seorang kepala daerah dalam media komunikasi merupakan kumpulan tanda-tanda dan simbol-simbol yang muncul mewakili realitas sosial yang ada dalam masyarakat. Keberadaan sebuah simbol menjadikan masyarakat lebih memahami apa yang tengah terjadi di sekitarnya karena dalam simbol tersebut terkandung pesan ataupun makna. Oleh karena itu, representasi sosial masyarakat yang berlaku pada waktu tertentu ada dalam karya tersebut.

Visualitas foto diri kepala daerah dalam media komunikasi secara kontekstual, bisa dilihat hubungan-hubungan sosial-politik tempat karya visual ini berada. Artinya, karya ini tidak dilihat sebagaimana yang tampak, tetapi seharusnya melihat yang tersembunyi di balik gambar tersebut. Dalam hal ini, tersirat adanya makna terkait hubungan-hubungan sosial-budaya dan politik yang tersembunyi di dalamnya. Akan tetapi, kehadiran karya ini juga bisa menjadi sangat berpengaruh terhadap dampak sosialpolitik karena karya ini mampu menggerakkan, mengubah sikap dan tingkah laku seseorang, bahkan masyarakat secara keseluruhan.

\section{METODE PENELITIAN}

\section{a. Metode dan Pendekatan}

Dalam kajian ini digunakan metode kualitatif deskriptif untuk memaparkan secara komprehensif dengan dibantu berbagai literatur. Analisis dilakukan secara kualitatif berdasarkan visualitas sebagaimana metode yang digunakan oleh Gillian Rose (2001) dalam bukunya Visual 
Methodologis yang meliputi teknologi, image, dan audiensi. Dalam konteks ini, teknologi berkaitan dengan bagaimana peran kamera atau fotografi dalam menciptakan gambar; sementara image tidak lain adalah karya foto itu sendiri yang di dalamnya terkandung elemen estetis. Sementara itu, audiensi merupakan sekumpulan masyarakat yang memiliki referensi sosial, politik, ekonomi, dan budaya yang bisa berbeda ketika mengonsumsi sebuah foto dalam media komunikasi. Melalui pendekatan visual sebagaimana yang dikonsepkan Walter Benjamin dalam menyikapi fenomena sosial, politik, dan ekonomi secara kritis melalui visualitas fotografi. Visualitas fotografi dalam konteks ini digunakan untuk menggambarkan citra visual yang dapat menarasikan melalui berbagai macam simbol visual.

\section{b. Fokus Kajian}

Dalam kajian ini objek penelitian difokuskan pada foto kepala daerah Bupati Klaten, Jawa Tengah di media komunikasi visual yang menunjukkan aktivitas di tengah pandemi Covid-19 dan diduga melakukan kampanye terselubung dalam pemilihan kepala daerah (Pilkada 2020). Objek kajian ini dipilih dengan pertimbangan antara lain:

1. Bupati Klaten telah melakukan kampanye terselubung di tengah pandemi Covid-19 dengan menempelkan foto diri disertai teks dalam bantuan sosial dari pemerintah sehingga mendapat teguran dari Badan Pengawas Pemilu Republik Indonesia (Bawaslu RI) dan dari Gubernur Jawa Tengah;

2. Bupati Klaten paling banyak disorot media massa lokal dan nasional, baik media massa cetak maupun media daring, dibanding kepala daerah lain yang diduga juga melakukan kampanye terselubung untuk Pilkada 2020 di tengah pandemi Covid-19;
3. Bupati Klaten memiliki kesadaran bermedia komunikasi visual yang tinggi. Hal ini dibuktikan dengan membuat berbagai bentuk media komunikasi visual (billboard, banner, poster, spanduk, dan yang lainnya) dan selalu mencantumkan foto dirinya dalam media tersebut. Selanjutnya, media tersebut secara masif dipasang di setiap sudut kota kabupaten dan kecamatan, bahkan di kantor instansi pemerintah, seperti puskesmas, rumah sakit, dan kantor kecamatan;

4. Selain itu, Bupati Klaten dilihat dari sisi fotografi merupakan figur yang 'camera face dan fotogenic', artinya ada kesadaran yang baik ketika berhadapan dengan kamera sehingga gambar foto yang ditampilkan menarik jika dilihat dari sisi ekspresi dan pose-posenya.

\section{PEMBAHASAN}

a. Visualitas Fotografi dan Politik

Visualitas fotografi adalah suatu penggambaran akan citra visual melalui berbagai macam simbol dan tanda visual yang terdapat di dalamnya. Oleh karena itu, gambar/ foto harus memungkinkan individu untuk menilai dengan cara menghubungkan tandatanda yang ada dengan fakta yang sebenarnya sesuai sifat fotografi itu sendiri. Selain itu, fotografi sebagai sebuah karya visual pada dasarnya juga memiliki perspektif persuasi yang bertujuan untuk memengaruhi audiensi, baik dari sisi psikologis maupun perilaku. Daya tarik dan persuasi yang ditimbulkan dari gambar foto inilah maka, karya ini banyak dimanfaatkan untuk kepentingan-kepentingan tertentu dengan tujuan-tujuan tertentu pula, termasuk untuk kepentingan politik.

Dalam kajian ini, visualitas fotografi untuk kepentingan politik telah banyak dimanfaatkan 
oleh berbagai pihak, salah satunya oleh Bupati Klaten, Jawa Tengah. Tanda utama politisasi dalam fotografi yang dirancang Bupati Klaten ini tecermin dalam pesan yang disampaikan secara visible (visual/gambar) dan invisible (pesan dan nilai di balik gambar). Konsekuensi pesan-pesan visual dalam gambar (foto) $\mathrm{Hj}$. Sri Mulyani selaku Bupati Klaten telah mengalami penyaringan dan sterilisasi melalui konvensikonvensi yang iamiliki selaku penguasa wilayah. Dalam hal ini, foto sosok Bupati Klaten dalam media komunikasi visual sengaja dirancang dengan tujuan untuk menggiring massa (calon pemilih/konstituen) untuk meneguhkan konstruksi sosial dan politik untuk kepentingan dalam Pemilihan Kepala Daerah (Pilkada) tahun 2020. Dalam praktiknya, banyak cara dan rekayasa yang dilakukan yang tujuannya untuk mendapatkan simpati dari masyarakat sebagai calon pemilihnya. Dalam istilah iklan yang menjadi esensi bukan kebenaran tetapi kepercayaan, seperti yang dikatakan Boorstin "...the essence of modern advertising is not truth but 'believability" (Leiss, William; Kline, Stephen; Jhally, 1986:60). Esensi dari iklan modern adalah bukan kebenaran, melainkan kepercayaan. Konsep Leiss dicoba dan diadopsi oleh Bupati Klaten saat ini, fotografi dijadikan sarana untuk kampanye layaknya iklan untuk Pilkada. Foto dirinya dalam media cetak tersebut digunakan untuk membentuk opini yang masuk pada kesadaran publik/masyarakat Klaten sekaligus bisa menjadi mesin untuk meraup suara di Pilkada 2020.

Fotografi dipandang oleh Barthes sebagai bentuk yang memiliki kekuatan, sebagaimana yang ditulis dalam buku berjudul Camera Lucida (Barthes, 1982:28), fotografi memiliki kekuatan yang luar biasa sekaligus membahayakan. Kekuatan fotografi ditunjukkan dengan kemampuan visualnya yang diyakini dapat menjadi daya tarik, daya bujuk (daya persuasi) terhadap audiensinya. Konsep pemikiran yang telah dibangun oleh Barthes tersebut digunakan pada rancangan visualitas fotografi dalam media komunikasi visual yang dilakukan $\mathrm{Hj}$. Sri Mulyani (Bupati Klaten) untuk kampanye Pilkada di tengah masa pandemi Covid-19. Mungkin, wabah masa pandemi merupakan momentum yang tepat untuk menyelinap dan melakukan berbagai aktivitas sosial ke masyarakat sekaligus melakukan kampanye untuk dirinya yang mencalonkan kembali di Pilkada 2020. Berbicara politik dalam hal ini adalah berbicara dalam konteks kekuasaan sebab substansi berpolitik tidak lain adalah untuk memengaruhi, menguasai, dan menanamkan ideologi-ideologi. Dalam hal ini $\mathrm{Hj}$. Sri Mulyani secara struktural merupakan pemilik kekuasaan di wilayah Kabupaten Klaten sehingga mempunyai kewenangan dan kebijakan tertentu di wilayahnya. Sebagai contoh di masa pandemi Covid-19, melalui foto dirinya dalam media komunikasi visual (billboard, poster, spanduk, banner, leaflet, dan lain sebagainya) bisa hadir/ dipasang di berbagai sudut jalan di wilayahnya, bahkan media-media tersebut juga ditempatkan di institusi-institusi pemerintahan untuk menyapa dan menyampaikan pesan tertentu. Hj. Sri Mulyani selaku bupati dapat melakukan aktivitas sosial pada masa pandemi Covid-19 secara leluasa, bisa masuk wilayah dan mengumpulkan masyarakat untuk menyampaikan bantuan sosial (bansos) yang berupa bahan pokok atau sarana dan prasarana kesehatan. Sebagaimana yang viral di media massa cetak dan media elektronik (medsos), Hj. Sri Mulyani melakukan kampanye terselubung dengan membagikan sembako dan alat kesehatan yang ditempeli foto dirinya dengan pesanpesan tertentu kepada masyarakat Klaten yang terdampak Covid-19. 
Dalam hal ini, visualitas fotografi untuk politisasi yang dilakukan Bupati Klaten sebagai upaya untuk menunjukkan kepedulian dan tanggung jawab sebagai seorang kepala daerah kepada rakyatnya dalam masa pandemi Covid-19 (lihat gambar 2). Selaras dengan yang dikatakan Benjamin dalam Buck-Morss (1989:312-322), kehadiran fotografi terikat erat dengan bangkitnya kebudayaan massa dan membutuhkan landasan. Landasan tersebut tidak lain adalah masyarakat sosial atau massa. Aspek sosial menentukan makna visualitas fotografi dari sudut analisis pola persuasi terhadap kehidupan sosial, budaya, dan politik. Aspek sosial tentang makna visualitas fotografi menguraikan bagaimana implikasi foto dalam media komunikasi dipersepsi oleh audiensi. Dalam konteks ini, bagaimana kaitannya dengan latar belakang, lingkungan sosial, budaya, ekonomi, dan tingkat pengetahuan politik masyarakat di wilayah Klaten dalam merespons visualitas foto bupatinya di berbagai bantuan sosial di tengah Covid-19.

Visualitas foto Bupati Klaten dalam media komunikasi visual, baik di baliho, poster, spanduk, dan media yang lain, merupakan sarana yang dirancang dan dibutuhkan untuk mencapai maksud, tujuan, dan dampak positif yang diinginkan. Dengan demikian, estetisasi visual digunakan tidak saja untuk mencapai keindahan saja, tetapi juga dapat dipakai untuk mengemas argumen dalam berkomunikasi untuk menunjukkan kredibilitas pengirim pesan yang tidak lain adalah $\mathrm{Hj}$. Sri Mulyani. Sebagaimana diketahui masyarakat Klaten, $\mathrm{Hj}$. Sri Mulyani yang masih menjabat Bupati Klaten periode 2017-2021, mencalonkan kembali untuk Pilkada 2020 (lihat gambar 3). Visualisasi foto diri $\mathrm{Hj}$. Sri Mulyani dengan berbagai pose (gaya) dan ekspresi, serta dengan mengenakan busana/pakaiannya bukan tanpa pertimbangan yang matang. Dalam politik kebudayaan gambar/foto dalam media bukan hanya semangat memperkenalkan diri semata, melainkan lebih merupakan semangat untuk memasukkan ideologi bagi para pembacanya. Sebagaimana dikatakan Barthes (1977:49), setiap gambar pada dasarnya mengandung “ideological of meaning”. Foto (gambar) dalam media untuk kampanye bukan sekadar karya artistik semata, melainkan di balik gambar sebenarnya beroperasi ideologi persuasi untuk sebuah tujuan tertentu. Unsur-unsur estetisasi dan ideologi sering bermain di balik figurel seseorang di media komunikasi. Sebagaimana juga terjadi pada foto diri $\mathrm{Hj}$. Sri Mulyani dalam melakukan kampanye terselubung di tengah pandemi Covid-19 ini.

Jadi, visualitas fotografi dalam media komunikasi visual merupakan suatu alat yang penting untuk mencapai maksud dan efek yang diinginkan sehingga estetika visual digunakan bukan saja untuk keindahan, melainkan dapat juga dipakai sebagai pengemas argumen untuk menunjukkan kredibilitas pengirim pesan yang terkait dengan maksud komunikator. Sebagaimana penampilan foto $\mathrm{Hj}$. Sri Mulyani sebagai kepala daerah dalam berbagai media komunikasi merupakan perangkat penting sebagai upaya agitasi pembentukan sosialpolitik (politik massa). Dalam budaya massa, nilai menyapa masyarakatnya merupakan bentuk sosiokultural Jawa yang lebih mengena, datang dari orang yang berkedudukan sangat tinggi di wilayah kekuasaannya. Sehubungan dengan hal itu, foto (gambar) Hj. Sri Mulyani dalam berbagai media komunikasi visual dapat dikatakan memiliki motivasi politis. Karena fotografi dalam media tersebut sengaja dirancang untuk tujuan mendapatkan simpati 
massa (konstituen), ada pesan dan harapan untuk meneguhkan konstruksi sosial menurut kepentingannya. Kehidupan sosial, budaya, dan politik telah dikooptasi oleh media gambar lewat fotografi yang dimediakan untuk membangun imajinasi konstituen. Foto $\mathrm{Hj}$. Sri Mulyani dalam berbagai media tersebut tidak hanya menggambarkan wanita cantik berkerudung yang selalu menebar senyum, yang dapat dipersepsikan atau dimaknai sebagai seorang wanita yang taat beragama, yang bisa dilihat dari atribut yang dikenakan dan gelar hajah $(\mathrm{Hj})$ di depan namanya. Penggambaran (pencitraan) sebagai wanita santun dan ramah terlihat dari ekspresi yang diperlihatkan dengan visual foto murah senyum. Hal ini tidak hanya dapat dilihat secara visible (visual), tetapi juga secara invisible, ada makna atau pesan di balik gambar tersebut. Merujuk ke budaya visual (visual culture) seperti yang dilakukan $\mathrm{Hj}$. Sri Mulyani menjadi bagian dari kehidupan sosial dan merupakan hiperrealitas karena di dalamnya melukiskan realitas yang mengatasi realitas real (hyperreality), realitas yang cantik dari yang cantik, lebih benar dari yang benar. Hiperrealitas tidak diproduksi, tetapi selalu siap direproduksi sebagaimana disebutkan Baudrillard (Ismanto, 2018:71-72).

\section{b. Foto Bupati Klaten dalam Bantuan Sosial di Tengah Pandemi Covid-19}

Sejak menjabat Bupati 2017, Hj. Sri Mulyani tidak banyak memunculkan kontroversi atas kebijakan-kebijakan yang diambilnya. Akan tetapi, sejak menjelang akhir tahun 2019, tepatnya November 2019 ada kontroversi yang cukup mengagetkan, yaitu ketika ada agenda pembagian sepeda motor matic NMAX ke 401 desa/kalurahan dan 26 kepala seksi ketertiban yang keseluruhannya menyerap Anggaran Pendapatan Belanja Daerah (APBD) sebesar
Rp11 miliar. Selanjutnya disusul peristiwa terjadinya wabah Covid-19 yang melanda dunia termasuk di Indonesia pada awal tahun 2020, Hj. Sri Mulyani memanipulasi dan memanfaatkan bantuan dari Kementerian Sosial untuk kampanye terselubung Pilkada tahun 2020 karena foto dirinya dengan mengenakan pakaian resmi bupati ada di botol hand sanitizer, disertai tulisan Hand Sanitizer, Bantuan Bupati Hj. Sri Mulyani, selanjutnya di bagian bawah ada slogan: Klaten Keren. Faktanya, bantuan hand sanitizer tersebut datang dari Kementerian Sosial atau Pemerintah Republik Indonesia, tetapi diklaim (diaku) sebagai bantuan Bupati Klaten (lihat Gambar 1).

Klaim bantuan atas nama bupati tersebut, sejauh apa pun ditutup-tutupi dan disamarkan, dalam praktiknya akan diketahui oleh masyarakat. Masyarakat Klaten menilai klaim atau tindakan mengaku-aku atas sesuatu bantuan yang datang dari pihak lain diaku miliknya merupakan perilaku di luar batas etika-sosial. Dengan demikian, peristiwa bantuan hand sanitizer yang berlabel stiker ada foto Bupati Klaten menjadi pemberitaan di media cetak, media online, dan viral di media sosial. Desain dengan bahan stiker yang ditempel pada botol hand sanitizer tersebut dengan latar belakang merah dipadu dengan foto bupati dengan stelan lengkap pakaian resmi berwarna putih sehingga paduan warna merah dan putih ini sangat menarik perhatian orang yang menerima dan membacanya. Dalam posenya wajah bupati menghadap ke depan, mata menatap ke arah kamera, dengan ekspresi tersenyum dan tangan kanan mengepal di depan dada. Gaya dan ekspresi yang ditampilkan pada foto tersebut dapat dimaknai sebagai seorang pemimpin daerah yang ramah dan siap menyapa atau berkomunikasi dengan masyarakatnya. 
Gestur tangan menggenggam di depan dada menunjukkan kesiapannya mengajak dan bersama-sama masyarakat menghadapi dan melawan Covid-19. Dalam konteks ini, foto Bupati Klaten Sri Mulyani sebagaimana dikatakan oleh Kress dan Leeuwen disebut citra yang meminta (demand), maka bentuk interaksinya adalah ajakan secara langsung. Arah tatapan subjek foto akan memengaruhi bentuk keterlibatan terhadap pemirsa. Tatapan langsung ke arah pemirsa akan menghasilkan laku pencitraan (image act) yang memberi pesan ajakan langsung kepada pemirsa untuk terlibat atau melakukan sesuatu (Susanto \& Irwandi, 2020:4).

Ternyata foto bupati yang sama juga digunakan pada media leaflet atau poster indoor untuk bantuan pengurangan atau diskon tagihan rekening air minum bagi pengguna di wilayah Klaten selama tiga bulan pada masa Covid-19. Di media komunikasi, informasi tersebut disusun sedemikian rupa untuk foto bupati lebih menonjol sehingga mendapatkan perhatian yang paling besar. Di bawah foto bupati terdapat teks: Hj. Sri Mulyani Bupati Klaten, Kami peduli terhadap dampak Covid-19. Kata 'Peduli' tersebut menjadi kata kunci dan penting dari seorang pemimpin pada masa wabah Covid-19. Peduli merupakan sikap untuk memerhatikan nilai-nilai kemanusiaan dan selalu tergerak untuk membantu kesulitan manusia lain. Sikap 'Peduli' telah dicobapraktikkan Bupati Klaten $\mathrm{Hj}$. Sri Mulyani sebagai seorang pemimpin daerah untuk memaknai dan melakukannya. Sebagaimana ditunjukkan $\mathrm{Hj}$. Sri Mulyani untuk senantiasa hadir dan ikut merasakan penderitaan orang lain, ikut merasakan penderitaan adanya wabah Covid-19 ini. Rasa peduli dan empati itu dibuktikan dengan bantuan-bantuan sosial yang diberikan ke sebagian masyarakat yang terdampak. Berusaha membantu mengurangi kesulitan ekonomi atas keadaan yang memberatkan masyarakat kecil.

Persoalan foto wajah Bupati Klaten yang fenomenal dan menjadi sorotan tidak hanya di hand sanitizer dan diskon rekening air minum, tetapi juga muncul di kemasan beras. Foto Bupati Klaten dengan pose dan pakaian yang berbeda dengan yang ada di hand sanitizer dan diskon rekening air minum. Di kemasan beras terpampang foto $\mathrm{Hj}$. Sri Mulyani dengan pose menghadap frontal ke depan menatap lensa kamera, ekspresi tersenyum dengan memakai hijab/kerudung warna merah dipadu dengan baju kebaya warna hitam. Gestur kedua tangan di depan badan (istilah Jawa: ngapurancang). Istilah ngapurancang adalah istilah yang digunakan untuk menunjuk ke sikap atau posisi berdiri dengan tangan berada di bawah pusar. Sikap dengan posisi tangan ini menunjukkan rasa hormat terhadap lawan yang mau diajak bicara, memperlihatkan sikap rendah hati, dan mau mendengarkan aspirasi orang lain (https://jogjapolitan.harianjogja.com/ $\mathrm{read} / 2019)$. Di label kemasan tersebut selain ada foto bupati juga disertai teks/ tulisan berupa informasi-informasi terkait kandungan beras dan cara memasaknya. Dari teks/tulisan yang menonjol, yaitu warna merah yang diletakkan di depan bawah foto berbunyi Beras Rojolele SRINUK Organik. Selanjutnya di bagian agak ke bawah ada tulisan Kementerian Pertanian, artinya produk beras ini berada di bawah Kementerian Pertanian Republik Indonesia (lihat gambar 1).

Kepedulian $\mathrm{Hj}$. Sri Mulyani sebagai Bupati dan Kepala Gugus Tugas Covid-19 juga hadir melalui foto-foto dirinya dalam media billboard/baliho di pinggir jalan dan di sudut-sudut wilayah Klaten. Kepedulian 
yang disampaikan dalam baliho/billboard tersebut adalah terkait penanganan Covid-19 dan membangkitkan semangat masyarakat Klaten untuk melawannya. Merupakan hal yang wajar dan sudah sepatutnya jika pemimpin harus peduli kepada rakyatnya, begitu juga sebaliknya rakyat juga harus peduli kepada pemimpinnya. Sebagaimana yang dijelaskan dalam Teori Peran (Role Theory), peran menggambarkan interaksi sosial dalam terminologi aktor-aktor yang bermain sesuai dengan apa-apa yang ditetapkan oleh tata sosial masyarakat (Turner, 1993). Sesuai dengan teori ini, peran merupakan pemahaman bersama yang menuntun massa untuk berperilaku dalam kehidupan sosial dan bisa membawa harapanharapan. Artinya seseorang yang memiliki peran tertentu diharapkan agar seseorang tadi berperilaku sesuai dengan peran tersebut. Dalam hal ini telah digambarkan oleh $\mathrm{Hj}$. Sri Mulyani selaku Bupati Klaten yang memiliki peran sebagai pemimpin daerah, maka beliau karena jabatannya, memiliki tanggung jawab dan kewenangan untuk menjamin keselamatan dan kesejahteraan bagi rakyatnya. Demikian pula seharusnya, dia juga harus memiliki perilaku yang bisa menjadi contoh rakyat yang dipimpinnya karena perilaku ini juga ditentukan oleh peran sosialnya.

Melihat, membaca, dan mencoba memahami fenomena visualitas foto $\mathrm{Hj}$. Sri Mulyani selaku Bupati Klaten yang disertakan/ ditempelkan pada barang-barang bantuan sosial di tengah pandemi Covid-19 merupakan upaya kampanye terselubung. Konsep kampanye yang dibangun dan tindakan yang dilakukan bupati selaku kepala daerah mudah dibaca masyarakat dan menjadi sangat sensitif dalam situasi di tengah menghadapi wabah Covid-19. Seperti diketahui, masyarakat pada masa wabah pendemi Covid-19 seperti ini sangat membutuhkan banyak hal seperti hand sanitizer, bahan pangan (sembako), dan kebutuhan vital lainnya. Para pemimpin pemerintahan baik pusat maupun daerah fokus dan berupaya memberikan bantuan sosial untuk menjaga dan menyelamatkan rakyatnya. Akan tetapi, bila ada pemimpin daerah yang melakukan kegiatan kemanusiaan 'berbagi' bansos yang berbalut kampanye terselubung demi kepentingan politik praktis merupakan momen yang tidak tepat. Sebagaimana yang dilakukan Bupati Klaten, yang pada akhirnya menjadi sorotan masyarakat dan berbagai media cetak serta viral di media sosial. Gubernur Jawa Tengah Ganjar Pranowo menyampaikan teguran yang menyebutkan tidak etis situasi pandemi korona seperti ini masih ada seorang Bupati memanfaatkan kesempatan untuk kepentingan kampanye terkait Pilkada 2020. Teguran untuk Bupati Klaten juga datang dari Badan Pengawas Pemilu (Bawaslu) untuk tidak melakukan kampanye di tengah pandemi Covid-19 dengan cara menyertakan foto dirinya di setiap bantuan sosial kepada masyarakat yang terdampak.

Hal ini dianggap biasa menurut teori classical conditioning dari Ivan Pavlof, yaitu sebuahfenomena"biasa"karenaterbiasa(Pavlov dalam Feldman, 2019). Pavlov beranggapan bahwa tingkah laku organisme dapat dibentuk melalui pengaturan dan manipulasi lingkungan. Jadi, classical conditioning sebagai pembentuk tingkah laku melalui proses persyaratan (conditioning process). Classical conditioning mengutamakan perilaku atau perubahan tingkah laku organisme melalui hubungan stimulusrespons. Artinya pembentukan kebiasaan dengan cara menghubungkan perangsang (stimulus) yang lebih kuat dengan perangsang yang lebih lemah. Dalam hal ini dapat dimaknai 
'stimulus yang kuat adalah $\mathrm{Hj}$. Sri Mulyani selaku bupati/pejabat daerah di Klaten yang memiliki tanggung jawab dan kewenangan' dan yang menjadi 'stimulus yang lemah' adalah masyarakat di wilayah Klaten. Bupati Klaten sebagai penguasa wilayah memiliki kekuatan untuk mengatur serta mengambil kebijakan tertentu terhadap masyarakatnya. Melihat secara komprehensif dengan tujuan awal bahwa adanya pesan politik yang disampaikan dalam tindakan yang "disengaja" dirancang untuk tujuan tertentu. Foto $\mathrm{Hj}$. Sri Mulyani dalam media komunikasi visual, baik di baliho, poster, spanduk, maupun media lain merupakan cara dan strategi di tengah pandemi Covid-19 yang ditengarai bahwa ada oknum yang telah melakukan kampanye terselubung. Tanda/ indikator kampanye terselubung tersebut adalah dengan mencantumkan/menempelkan foto dirinya pada barang yang diberikan kepada masyarakat penerima bantuan.
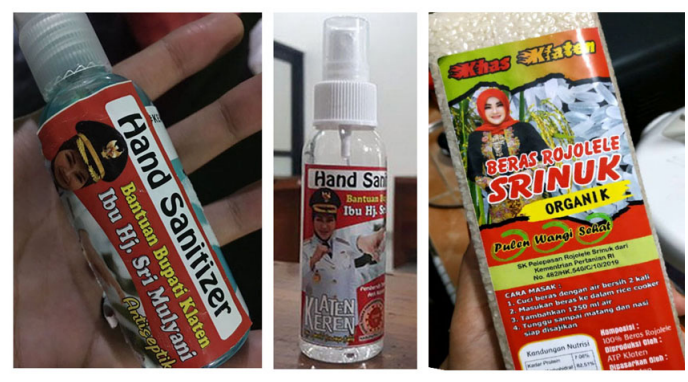

Gambar 1

Foto Hj. Sri Mulyani (Bupati Klaten) di label hand sanitizer dan paket kemasan beras SRINUK

Sumber: https://hits.grid.id/read/482126814/ heboh-wajah-bupati-klaten
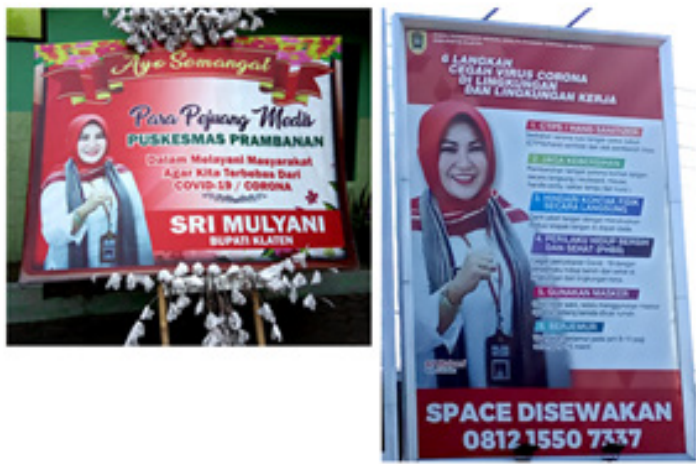

Gambar 2

Foto Hj. Sri Mulyani (Bupati Klaten) yang ditempatkan di instansi pemerintahan. Sumber: Dokumentasi Prayanto, 2020

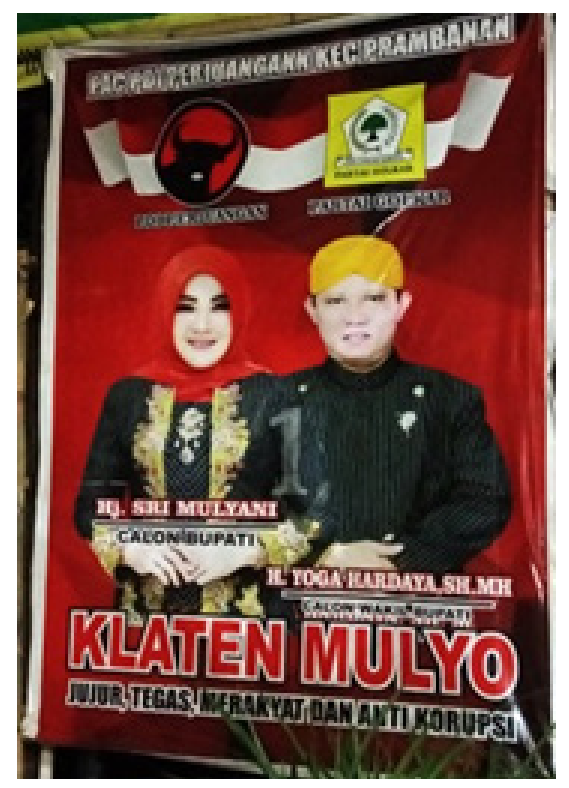

Gambar 3

Eksistensi Bupati Klaten Wajah Hj. Sri Mulyani (Bupati Klaten) pada masa pandemi Covid-19 ini dapat ditemui di berbagai media yang terpasang di berbagai sudut kota kecamatan dan Kabupaten Klaten. Sumber: Dokumentasi Prayanto, 2020 


\section{SIMPULAN}

Visualitas gambar foto kepala daerah merupakan pendekatan visual dalam political branding yang dilakukan oleh pejabat publik sebagai upaya persuasi serta intervensi sosial kepada masyarakat calon pemilih dalam menentukan pilihan kepala daerahnya. Visualitas foto diri Bupati Klaten dalam media komunikasi visual sebagai bentuk politisasi sebagai konsekuensi lahirnya upaya penafsiran terhadap fakta atau realitas sosial. Oleh karena itu, pesan yang diciptakan melalui medium fotografi dalam media komunikasi untuk mengendalikan khalayak dengan cara menghubungkan perannya sebagai pejabat daerah. Dalam konteks ini adalah peran bupati (Hj. Sri Mulyani) dengan menuntun massa bersama dalam kehidupan sosial dan bisa membawa harapan-harapan. Operasionalisasi komunikasi politik yang dilakukan disebut "strategi" membangun legitimasi, bentuk, dan konvensi dari persepsi indrawi dengan tujuan memenangkan pertarungan di Pilkada tahun 2020 untuk mendapatkan kekuasaan kembali.

Namun, fenomena politik dalam Pilkada 2020 di tengah wabah Covid-19 dengan munculnya kampanye terselubung menjadi peristiwa yang tidak etis dan tidak tepat dilakukan seorang pejabat publik untuk kepentingan politik yang sifatnya pragmatis. Hadirnya foto $\mathrm{Hj}$. Sri Mulyani sebagai bupati di berbagai media komunikasi visual adalah sebagai penyalur pesan yang bersifat sosiologis dan politis. Oleh karena itu, fotografi menjadi salah satu elemen penting dan strategis untuk kampanye dalam menghadapi pemilihan kepala daerah karena foto dilihat dari fungsinya memiliki daya tarik dan persuasi yang kuat untuk membantu memperjelas dan memperteguh isi pesan terhadap konstituen atau masyarakat.

\section{KEPUSTAKAAN}

Amala, M. (2016). Penciptaan Fotografi Surealisme Human and Time. REKAM: Jurnal Fotografi, Televisi, Animasi, 12(2), 131-142. $\quad$ https://doi.org/https://doi. org/10.24821/rekam.v12i2.1430

Barthes, R. (1977). Image Music Text. London: Fontana Press.

Barthes, R. (1982). Camera Lucida: Reflections on Photography. United State: Hill and Wang; First edition.

Buck-Morss, S. (1989). The Dialectics of Seeing: Walter Benjamin and the Arcades Project (Studies in Contemporary German Social Thought). USA: The MIT Press; Harvard University Press.

Feldman, R. S. (2019). Essentials of Understanding Psychology-13th Edition. New York: McGraw-Hill Education.

Harper, D. (2012). Visual Sociology. USA: Routledge.

Ismanto, I. (2018). Budaya Selfi Masyarakat Urban: Kajian Estetika Fotograf, Cyber Culture, dan Semiotika Visual. REKAM: Jurnal Fotografi, Televisi, Animasi, 14(1), 67-76. https://doi.org/https://doi. org/10.24821/rekam.v14i1.2138

Jameson, F. (1977). Aesthetics and Politics. Great Britain: Whitstable Litho Ltd.

Jazuli. (2014). Manajemen Seni Pertunjukan. Yogyakarta: Graha Ilmu.

Leiss, William; Kline, Stephen; Jhally, S. (1986). Social Communication in Advertising: Persons, Products, \& Images of Well-being. United Kingdom: Methuen Publishing Ltd.

Rose, G. (2001). Visual Methodologies: An Introduction to the Interpretation of Visual Materials. Retrieved from https:// www.academia.edu/9370225/Handbook Of_Visual_Communication_Theory_ Methods_And_Media

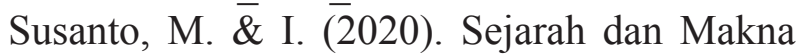 Fotografi Karya Pelukis Istana, Dullah. REKAM: Jurnal Fotografi, Televisi, Animasi, 16(1), 1-14.

Turner, J. H. (1993). Sociology, Concepts, and Uses. United State: McGraw-Hill College.

\section{Webtografi}

Bramasta, D. B. (2020). Mengintip Jejak Bupati Klaten Sri Mulyani, dari Bagi-bagi Nmax hingga Heboh Hand Sanitizer. Retrieved 
May 15, 2020, from kompas.com website: https://www.kompas.com/tren/ $\mathrm{read} / 2020 / 04 / 28 / 093200965 /$ mengintipjejak-bupati-klaten-sri-mulyani-dari-bagibagi-nmax-hingga-heboh?page=2

Dita, S. (2020). Heboh Wajah Bupati Klaten Muncul di Hand Sanitizer hingga Berujung Klarifikasi, Mantan Wakil Ketua KPK Singgung Soal Malunya Sri Mulyani. Retrieved May 15, 2020, from GridHITS.id website: https://hits.grid. $\mathrm{id} / \mathrm{read} / 482126814 /$ heboh-wajah-bupatiklaten-muncul-di-hand-sanitizer-hinggaberujung-klarifikasi-mantan-wakilketua-kpk-singgung-soal-malunya-srimulyani?page $=$ all

Syauqi, A. (2020). Jejak Politik Bupati Klaten yang Jadi Trending Topic Gegara Hand Sanitizer. Retrieved May 15, 2020, from detikNews website: https://news.detik. com/berita-jawa-tengah/d-4994702/jejakpolitik-bupati-klaten-yang-jadi-trendingtopic-gegara-hand-sanitizer/3

https://images.solopos.com/2019/11/motordinas-klaten-2-1200x900.jpg pada 15 Mei 2020.

h t t p s : // m.t rib un n e w s. co m / nasional/2019/07/12/caleg-dpd-ntbdigugat-akibat-edit-foto-di-luar-bataskewajaran-hingga-terlihat-cantik-danmenarik? page $=3$ ).

https://jogjapolitan.harianjogja.com/ $\mathrm{read} / 2019 / 01 / 15 / 510 / 965212 / \mathrm{mengenal}-$ makna-posisi-tangan-dalam-foto-dhaupageng-pura-pakualaman 
